\title{
Review on biological process of soil improvement in the mitigation of liquefaction in sandy soil
}

\author{
Abubakar Sadiq Muhammed ${ }^{1,2 *}$ Khairul Anuar Kassim ${ }^{1}$, and Muttaqa Uba Zango ${ }^{1,3}$ \\ ${ }^{1}$ Faculty of Civil Engineering, Universiti Teknologi Malaysia, 81310 Johor Bahru, Johor, Malaysia \\ ${ }^{2}$ Department of Civil and Water Resources Engineering, Unimaid, P. M. B. 1069, Maiduguri. Borno \\ State, Nigeria \\ ${ }^{3}$ Department of Civil Engineering, KUST Wudil, P. M. B. 3244, Kano State, Nigeria
}

\begin{abstract}
Recently, the concept of using biological process in soil improvement otherwise called bio-mediated soil improvement technique has shown greater prospects in the mitigation of liquefiable soils. It is an environmental friendly technique that has generated great interest to geotechnical engineers. This paper presents a review on the microorganism responsible for the biological processes in soil improvement system, factors that affect biological process, identifying the mechanism of liquefaction and commonly adopted method to mitigate liquefaction. Next, the effect of microbial induced calcite precipitation (MICP) on the strength and cyclic response were also analyzed, where it was identified that higher cementation level leads to formation of larger sized calcite crystals which in turn leads to the improved shear strength, stiffness and cyclic resistance ratio of the soil. However, the effects of various bacteria, cementation reagent concentrations amongst other factors were not fully explored in most of the studies. Finally, some of the challenges that lay ahead for the emerging technology are optimizing treatment factors (bacteria and cementation reagent concentration), upscaling process, training of researchers/technologist and long - time durability of the improved soils.
\end{abstract}

\section{Introduction}

Rapid urbanization and population growth in most developing countries has led to more demand for civil infrastructures, which are erected over limited available lands. Some of these infrastructures are built in low lands, lakes, rivers, that are being filled to build such structures. In most cases these land reclamation (filling) are done with local available river sand which are sometimes liquefiable. Liquefaction is a phenomenon that occurs in loose, saturated cohesionless soil, which has tendency to deform under monotonic, transient, or repeated loading under undrained condition. The soil undergoes an increase in excess pore water pressure and a consequent reduction in effective stress. Liquefaction can be triggered

\footnotetext{
* Corresponding author: sadiq4civil@ yahoo.com
} 
by earthquakes, rise in ground water pressure, slope steepening, over-loading, machine vibrations and cyclic loading in general. If these occur, soil tends to act like liquid and the shear strength and stiffness of the soil are drastically reduced [1]. Infrastructures developed on liquefiable prone soils are susceptible to damage when earthquake occurs [2]. Therefore, it important to explore safety techniques that can help prevents or reduces the effect of liquefaction on exiting infrastructures.

The most common soil improvement techniques include densification of the soil through mechanical energy, preloading to achieve consolidation, addition of chemical admixture and grouting with synthetic materials such as cement, epoxy, and sodium silicate [3]. However, most of these conventional chemical admixtures and grouting materials have raise environmental concerns $[4,5]$. Furthermore, production of some of these chemical additives (cement and lime) requires high amount of energy, money and it emits unwarranted carbon dioxide to the environment. In particular, the use of Ordinary Portland Cement (OPC) has a very high carbon footprint, introduce synthetics and sometimes toxic material into the environment [6]. Therefore, recent advances in geotechnical engineering have shown the potential use of bio-mediated systems to improve soil properties [7]-[9]. Bio-mediated or bio-improvement is a promising, environmentally friendly and sustainable alternative technique of improving the geotechnical properties of soil through microbial induced calcite precipitation [10].

Microbial induced calcite precipitation (MICP) technique utilizes bacteria (indigenous or introduced) to precipitate calcite, and to improve engineering properties of soils through formations of coating and bonds between soil particles [11]. Studies have shown that MICP can be used to decrease permeability, decrease compressibility, increase shear strength, stiffness and alter the volumetric behavior of soil [10]-[14]. This paper presents a review of the use of MICP as a mitigation technique for liquefiable soils. The mechanism of MICP and liquefaction of soil were introduced, basic factors that affect MICP and general effect of MICP on the geotechnical properties of soils. Finally, some research gaps are highlighted for future research and development.

\section{Mechanism and Mitigation of soil Liquefaction}

Liquefaction is occurs as a result of soil deformation caused by rapid loading of saturated cohesionless soils under undrained condition. It is a term generally used to define a situation in which saturated cohesionless soil is transformed from a solid state into a liquid state by static or cyclic loading thereby losing its stiffness and strength [1], [15]. Liquefaction can occur when a site with saturated relatively loose, cohesionless soils (usually sands or silts) experience strong cyclic loading during earthquakes. When seismic forces excite the saturated granular layers, the loose soil structure tends to contract generating excess pore water pressure, accompanied by a reduction in soils' strength. This causes the soil to behave as a viscous liquid rather than soil, at this point the soil is said to be liquefied. Soil liquefaction can have a range of unfavorable side effects. For example, liquefaction of soil beneath embankment and building can lead to flow slide and failure of shallow foundations respectively. Furthermore, liquefaction can lead to excessive ground subsidence, floating of buried structures, slope failure, loss of bearing capacity and dislocation of retaining wall [15]. In 2011, the damage by liquefaction was experienced when moderate (magnitude 6.3) Christchurch earthquake occurred in New Zealand and damaged about 15,000 single-family houses beyond repair [16].

Conventionally, there are quite a number of soil improvement techniques that can be used to mitigate liquefaction. Depending on the mechanism used to improve the geotechnical properties of the soil, the most common methods are divided into the following categories: drainage, densification, replacement, grouting and mixing techniques 
[17], [18]. Table 1 shows a summary of the working principles, advantage and disadvantages of some the methods used in the mitigation of liquefaction.

Table 1. Summary of advantage and disadvantage of some methods. [17]

\begin{tabular}{|c|c|c|c|}
\hline Method & Advantages & Disadvantages & Principle \\
\hline Dewatering & $\begin{array}{l}\text { Effective as a primary } \\
\text { step in water-logged } \\
\text { areas }\end{array}$ & $\begin{array}{l}\text { Costly as continuous } \\
\text { pumping is necessary }\end{array}$ & Drainage \\
\hline Earthquake drain & $\begin{array}{l}\text { Effective dissipation of } \\
\text { pore pressure }\end{array}$ & $\begin{array}{l}\text { Difficulty in treating a } \\
\text { single liquefiable layer }\end{array}$ & Drainage \\
\hline Vibratory Methods & $\begin{array}{l}\text { Stone columns tend to } \\
\text { dilate as they get sheared } \\
\text { during an earthquake } \\
\text { providing } \\
\text { anchorage }\end{array}$ & $\begin{array}{l}\text { Costly if a deep single } \\
\text { liquefiable layer need } \\
\text { to be treated }\end{array}$ & Densification \\
\hline $\begin{array}{l}\text { Deep Dynamic } \\
\text { Compaction }\end{array}$ & $\begin{array}{l}\text { Economic } \\
\text { improvement technique } \\
\text { for arrange porous soil } \\
\text { type }\end{array}$ & $\begin{array}{l}\text { Existing structures } \\
\text { acts as a hindrance }\end{array}$ & Densification \\
\hline $\begin{array}{l}\text { Permeation } \\
\text { Grouting, } \\
\text { Compaction } \\
\text { Grouting, Jet } \\
\text { Grouting }\end{array}$ & $\begin{array}{l}\text { Deep isolated liquefiable } \\
\text { layers can be treated }\end{array}$ & $\begin{array}{l}\text { Underground utilities } \\
\text { such as pipelines may } \\
\text { prove to be a } \\
\text { hindrance }\end{array}$ & $\begin{array}{l}\text { Compaction } \\
\text { and } \\
\text { Densification }\end{array}$ \\
\hline $\begin{array}{l}\text { Removal and } \\
\text { Replacement }\end{array}$ & $\begin{array}{l}\text { Reliable measure as } \\
\text { tendency of liquefaction } \\
\text { is eliminated }\end{array}$ & $\begin{array}{l}\text { Costly method to be } \\
\text { practiced }\end{array}$ & Replacement \\
\hline
\end{tabular}

The most common soil improvement techniques either make use high mechanical energy, addition of chemical admixture or grouting with synthetic materials such as cement, epoxy, and sodium silicate. However, the use of high mechanical energy can cause serious disturbance to existing building. While on the other hand, most of the conventional chemical admixtures and grouting materials are known to be harmful to the environment [10]. Recent advances in geotechnical engineering have shown the potential use of biomediated systems to improve soil properties [19]-[22]. Bio-mediated or bio-improvement is a promising, environmentally friendly and sustainable alternative technique of improving the geotechnical properties of soil through microbial induced calcite precipitation [4].

\section{Bio-mediated soil Improvement through Microbial Induced Calcite Precipitation}

Bio-mediated soil improvement is a technique that has shown greater prospects in geotechnical engineering, it involves the use of biological process in improving the properties of soils [4]. It is a system of network of chemical reaction that is controlled and managed within the soil by biological activities whose by-product changes the geotechnical properties of the soil. In general, it couples cost effectiveness and sustainability with drastic improvement in the geotechnical properties of soil [23]. Microbially Induced Calcite Precipitation (MICP) has been an important discovery in the field of geotechnical engineering. It is a field that has come to existence through interdisciplinary research involving microbiology, geotechnical engineering and geochemistry to improve the 
properties of soils [4]. Microbially induced calcite precipitation (MICP) technique utilizes bacteria (indigenous or introduced) to precipitate calcite into the soil matric. In order words, MICP is a process where calcium carbonate (calcite) is formed in a soil through biological process. This calcite produced binds the soil particles together through cementing and clogging which helps to increase the shear strength decrease void ratio, compressibility and hydraulic conductivity of the soil [10], [11]. This is achieved by introducing a large population of calcite forming microorganisms and cementation reagent into the soil matrix, thereby forming a cement compound that helps to generally improve the engineering properties of the soil. The process of calcium carbonate formation is divided into three steps: bacteria growth, bacteria metabolism and calcium carbonate precipitation. Although, the amount of calcite is determined along the profile of cemented soil or using nondestructive geophysical methods which helps to determine the level of cementation of the soil [24].

\subsection{Mechanism for soil improvement through Microbial Induced Calcite Precipitation}

Calcite $\left(\mathrm{CaCO}_{3}\right)$ is a product of microbial induced calcite precipitation (MICP) that can be produced through a variety of pathways. These alternatives include urea hydrolysis, denitrification, iron and sulfate reduction. Urea hydrolysis is the most desired $\mathrm{CaCO}_{3}$ precipitation method adopted by researchers because the process is straightforward and easily controlled [25]. In a very short period of less than 24 hours the process can produce up to $90 \%$ chemical conversion efficiency [26]. The mechanism described for MICP is the hydrolysis of urea by enzyme urease, which results in the production of carbonate ions in the presence of ammonium. The mechanism of $\mathrm{CaCO}_{3}$ precipitation by urea hydrolysis can be categorized into two stages: (1) urea hydrolysis and (2) $\mathrm{CaCO}_{3}$ precipitation [24].

$$
\begin{gathered}
\mathrm{CO}\left(\mathrm{NH}_{2}\right)_{2}+2 \mathrm{H}_{2} \mathrm{O} \rightarrow \mathrm{CO}_{3}^{2-}+2 \mathrm{NH}_{4}^{+} \\
\mathrm{Ca}^{2+}+\mathrm{CO}_{2}^{2-} \rightarrow \mathrm{CaCO}_{3}
\end{gathered}
$$

Quantitatively, during the urea hydrolysis stage, $1 \mathrm{~mol}$ of urea $\left(\mathrm{CO}\left(\mathrm{NH}_{2}\right)_{2}\right.$ is hydrolyzed to produce $1 \mathrm{~mol}$ of carbonate $\left(\mathrm{CO}_{3}^{2-}\right)$ and $2 \mathrm{~mol}$ of ammonia $\left(\mathrm{NH}_{4}{ }^{+}\right)$ions. The ammonia ions increase the local $\mathrm{pH}$, thereby creating a favorable environment for calcite precipitation. During the calcite $\left(\mathrm{CaCO}_{3}\right)$ precipitation stage, the introduced calcium ions $\left(\mathrm{Ca}^{2+}\right)$ derived from calcium chloride $\left(\mathrm{CaCl}_{2}\right)$ in the cementation solution reacts with the carbonate ions $\left(\mathrm{CO}_{3}{ }^{2-}\right)$ to form $1 \mathrm{~mol}$ of calcium carbonate $\left(\mathrm{CaCO}_{3}\right)$ crystals. Calcium carbonate $\left(\mathrm{CaCO}_{3}\right)$ is one of the most common and widespread minerals on earth, it is a common crystal found in rocks around the world and exists in the environments, such as marine water, fresh water, and soils [27]. Calcium carbonate (Calcite) precipitation is a relatively straightforward chemical process that is basically affected by four major factors; namely $\mathrm{pH}$, temperature, bacteria cell concentrations/availability of nucleation sites, concentration of cementation reagent, geometric compatibility [28, 29]. Furthermore, other environmental factors that affect the performance of calcite precipitation is the method of injection, soil type and particle size of the soil [9, 30, 31]. 


\subsection{1 $\mathrm{pH}$}

Formation of calcite commences when urea decomposes by urease enzyme at a favourable condition, which is normally alkaline in nature. Several studies reported that calcite precipitation occurs most under alkaline condition ranging from 7.5-9.5 [32, 33] except for a small group of acid ureases with optimum $\mathrm{pH}$ of near neutral [34]. Arunachalam[35] performed MICP treatment using Bacillus sphaericus, a $\mathrm{pH}$ of 8 was reported to be the peak for calcite precipitation. Khan (2011) reported that urease activity peaked at $\mathrm{pH} 7$ for Bacillus Megaterium. Similarly, studies carried out using Sporosacina pasteurii had optimum $\mathrm{pH}$ of 9.5[36], 9.1 [37], 9.3 [37] during the various formation of calcite. Generally, production of ammonia from urea hydrolysis will increase the $\mathrm{pH}$ medium during MICP process, while bicarbonate from urea hydrolysis and microbial respiration, on the other hand, acts as a buffer to the $\mathrm{pH}$ rise. Monitoring the $\mathrm{pH}$ of the effluent during MICP treatment is important to maintain the most favourable condition for calcite production because at very low $\mathrm{pH}$ carbonate tend to dissolve rather than precipitate.

\subsubsection{Temperature}

Calcite precipitation like any other enzymatic reaction is temperature dependent as it affects growth and urease activity of microorganism, nucleation rate and solubility of calcium carbonate. Whiffin [38] stated that urease activity of sporosarcina pasteurii increased proportionally with increase in temperature between $25^{\circ} \mathrm{C}$ and $60^{\circ} \mathrm{C}$. However, an optimum temperature of $70^{\circ} \mathrm{C}$ was attained after which the urease activity dropped significantly to almost half of the optimum urease activity at $80^{\circ} \mathrm{C}$. Similarly, Rebata-Landa [39] showed that at a temperature higher than $60^{\circ} \mathrm{C}$, the $\mathrm{CaCO}_{3}$ production ceased to occur due to the death of microorganisms. Furthermore, on the effect of temperature on MICP, [40] conducted a study to determine the effect of room $\left(25^{\circ} \mathrm{C}\right)$ and higher $\left(50^{\circ} \mathrm{C}\right)$ temperatures on the strength of MICP treated sand. It was found that calcite formed at $50^{\circ} \mathrm{C}$ was about three times more than that formed at room temperature. Recently, Chiet et al [41] evaluated the effect temperature variation on the performance of microbial calcite precipitates in residual soil, were a peak temperature of $50^{\circ} \mathrm{C}$ gave the highest strength gain with respect to the other lower temperatures.

\subsubsection{Geometric compatibility}

Bacteria are the most microorganisms found in soils with sizes ranging from 0.5 to $3.0 \mu \mathrm{m}$ [42]. One critical factor that affects MICP is the geometric compatibility of the urease producing bacteria with the soil in which they are injected into, as this affects the rate of movement of the bacteria within the soil. Soil microbe transport across soil through pore throats and between soil particles is either by self-propelled movement or by passive diffusion. Depending on the size of the microbes and soil compaction, small pore throat size will limit free movement within the soil. According to Mitchell and Santamarina [42] bacteria with size ranging from 0.3 to $2 \mu \mathrm{m}$ can move freely within sandy soil having particle sizes of 0.05 to $2.0 \mathrm{~mm}$. Although, significant amount of fine (silt and clay, size < $2 \mu \mathrm{m}$ ) in the soil would have inhibitory effect on movement of bacteria. Therefore, it is very important to take into consideration the size of the bacteria, soil type and pore throat size before the commencement of MICP process. 


\subsubsection{Bacteria Cell Concentration}

According to Okwadha and Li [43] high bacteria cell concentration in the soil would obviously increase the amount of calcite precipitated from the urea hydrolysis process. Therefore, the rate of urea hydrolysis has a direct relationship to the bacterial cell concentration, provided sufficient reactant concentrations are available [44, 45]. High bacterial concentrations produce more urease per unit volume to induce urea hydrolysis. Stocks-Fisher et al. [33] reported that bacterial cell concentration serves as a nucleation site for calcite precipitation process and recently $\mathrm{Xu}$ et al. [46] observed the same phenomenon. Okwadha and Li [43] carried out a study using sporosarcina pasterurii to evaluate the effect of bacterial cell concentration, urea and calcium ions concentration on the precipitation of calcite. The results indicated that the rate of calcite formation increased with bacterial cell concentration, and the bacterial cell concentration had a greater influence on rate of calcite than initial urea concentration. In a study carried out by Chou et al. [47] to compare performance of bio-mediated sand samples at different bacteria concertation shows that, frictional angles of soil treated at $10^{7} \mathrm{cfu} / \mathrm{ml}$ were greater than that of $10^{3} \mathrm{cfu} / \mathrm{ml}$. [48] used Klebsiella pneumoniae to evaluate the effect on bacterial cell concentration on the strength and hydraulic conductivity of a residual soil. The results obtained indicated a general increase in the strength of the treated soil, while the hydraulic conductivity decreased with increase in bacteria concentrations. This is an indication that a higher bacteria concentration precipitates more calcite for binding and clogging the soil particles that lead to increase in strength and reduction in permeability respectively.

\subsubsection{Concentration of cementation reagent}

Another factor that affect the precipitation of calcite is the concentration of cementation reagent which serves as essential ingredients for precipitating calcite. Quiet a number of studies have been carried out to check the effect of concentration of cementation reagent on the geotechnical properties different soils $[11,49]$. Results of a study by Umar et al [48], results shows an increase in strength with increase in reagent concentration up to $0.5 \mathrm{M}$ after which a decline in strength was noticed at values higher than $0.5 \mathrm{M}$. Similarly, Chiet et al. [51] found that the most optimal concentration of cementation reagent is $0.25 \mathrm{M}$ for MICP treated residual soil. Al-Qabany et al. [52] also found out that lower cementation reagent (lower or equal to $0.25 \mathrm{M}$ ) gave rise to higher unconfine compressive strength values. From these few studies it can be deduced that MICP is more efficient at lower concentration of cementation reagent, however, more investigation should be carried out to ascertain the level of cementation with different concentration of cementation reagent.

\section{Effect of MICP on the cyclic response of soil}

The use of bio-mediated technique through MICP in the mitigation of liquefaction can be assessed based on the dynamic properties and liquefaction resistance of the improved soil. [53]-[55] conducted series of undrained cyclic triaxial test on sand cemented through microbial induced calcite precipitate. The liquefaction resistance was evaluated by comparing the cyclic stress ratio with the number of cycles needed to cause $5 \%$ double amplitude axial strain for treated and untreated sand. All studies attributed the increase in liquefaction resistance to effectiveness of calcite formation that precipitated at the interparticle points, thus increasing the stiffness of the treated soil. In a similar study, [56] also observed an increase in cyclic stress ratio of the MICP treated sand when compared to the untreated soil Burkank et al. [57] demonstrate that natural indigenous bacteria can also be stimulated to induce calcite precipitation. Results from their study showed that the cyclic 
resistance ratio of soil treated using MICP can be increased by as much as four times for calcite precipitation level ranging from 3.8 to $7.4 \% \mathrm{CaCO}_{3}$. These results indicate that moderate amounts of carbonate precipitation via MICP may be enough to significantly improve the liquefaction resistance of the soil. Furthermore, comparing the cyclic stress ratio (CSR) for sand treated with Portland cement and bio-cement showed that CRS for biocement treated sand was higher than that of the cement-treated soil at similar quantity of cementation content. Similarly, conducting undrained shear strength and dynamic triaxial tests on the mechanical properties of MICP treated sand found out that strength and liquefaction resistance was greatly improved, this is in consistent with previous studies [8].

Calcite content is directly related to the level improvement of a soil treated with microbial induced calcite precipitate, therefore obtaining an appropriate method to determine the level of cementation is important. In a study by Feng and Montoya [58], conducted laboratory testing to quantify cementation of soil sample subjected to cylindrical loading, where it was identified that the calcite content may not be the only appropriate method to characterize the properties of MICP treated soil sample. Two samples were prepared having approximately the same mass of calcite when subjected to cyclic loading, however both soil exhibit different resistance to cyclic strain and excess pressure, thereby making $V s$ a better indication of the improved property of the soil. Samples treated at shear wave velocity of $425 \mathrm{~m} / \mathrm{s}$ and $676 \mathrm{~m} / \mathrm{s}$ experienced 100 and 963 cycles respectively before it suffered significant strain and excess porewater pressure. Therefore, soils with higher shear wave velocity have exhibits larger resistance to liquefaction.

Other method to determine the rate of improvement of an MICP treated liquefiable soil is by using a geotechnical centrifuge test. A centrifuge test and cyclic direct simple shear to assess the effect of microbial induced calcite precipitate (MICP) on the liquefaction resistance of treated sand relative to the untreated[2,59]. This was determined based on the generation of excess water pressure and deformation in sand beneath the structure with MICP treatment. Results showed that MICP can be used as a ground improvement technique because of reduction in both the excess water pressure and ground deformation. Furthermore, in the cyclic direct simple shear test, the cyclic stress ratio (CRS) of the MICP-treated sand increased by 0.3 as compared with the sand without treatment. Generally, increase in liquefaction resistance of MICP - treated soil is not only due to calcite filling the void spaces, but also calcite- coating of the soil particle which helps to increase the inter - grain bonding.

Table 2 shows some recent literature on MICP treatment on sandy soil, the type of bacteria used, cementation medium and some basic steps in the sample preparation and treatment. 


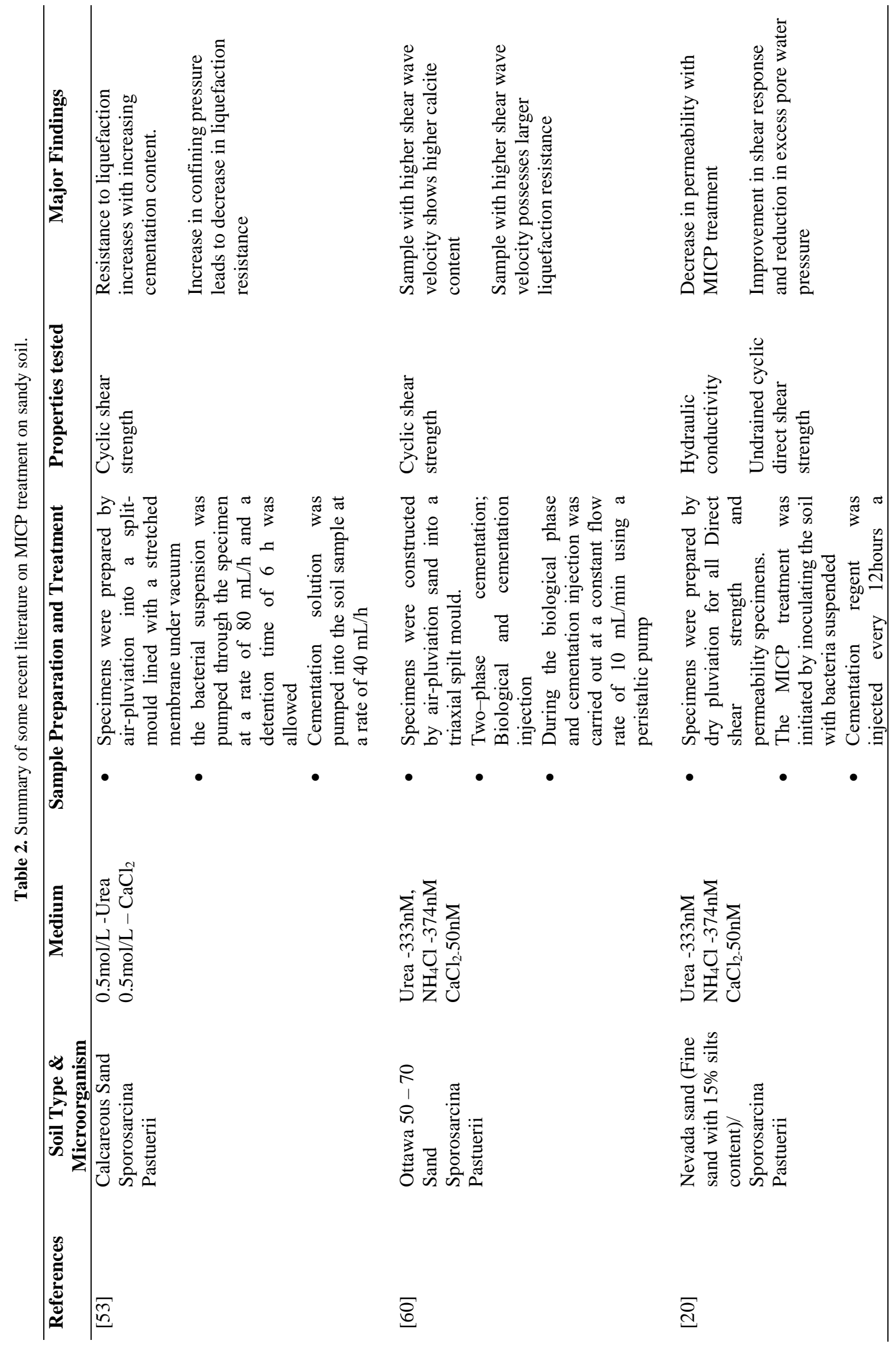



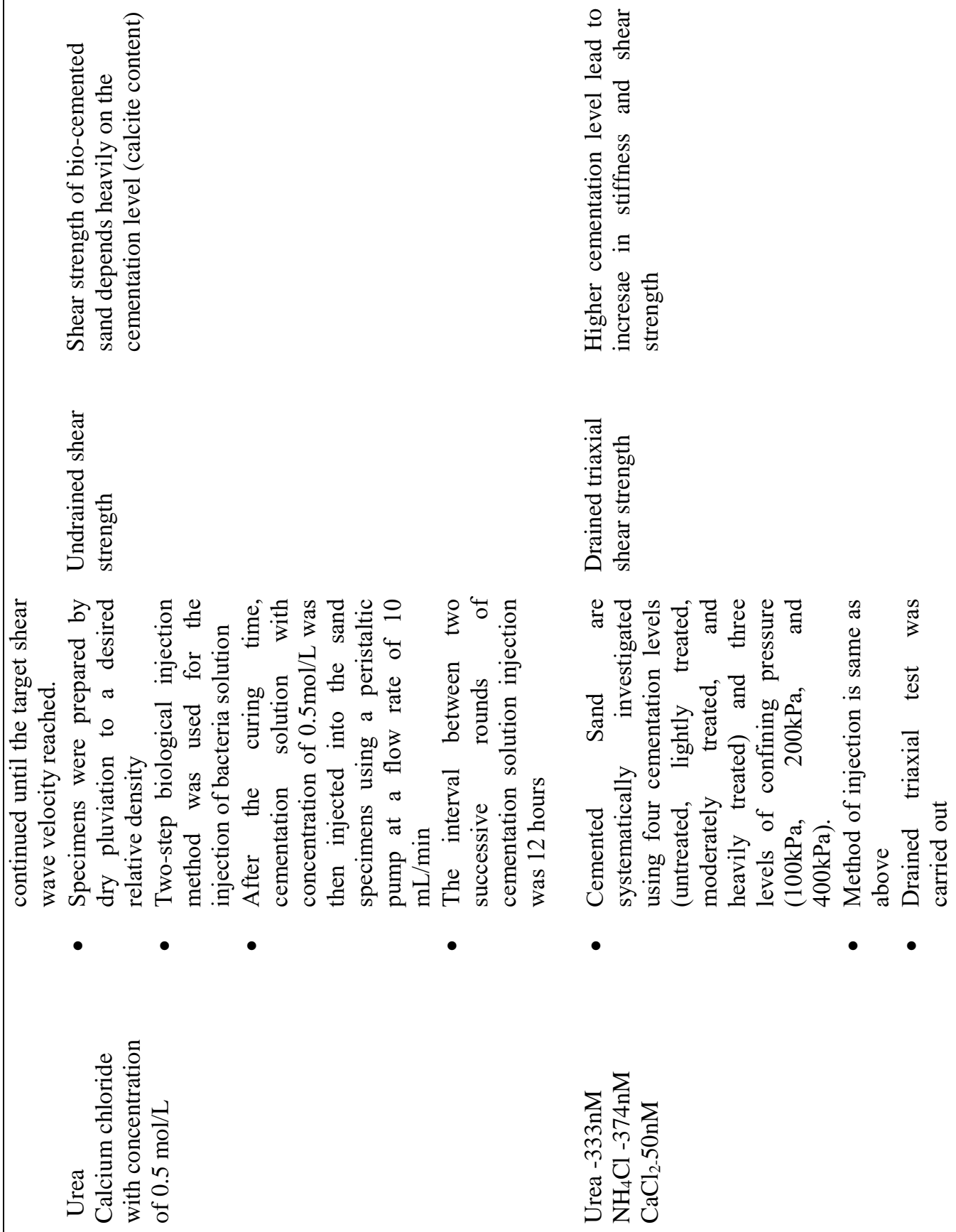

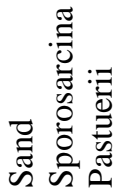

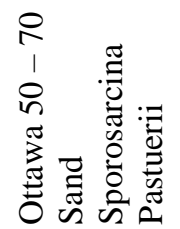

$\bar{\Xi}$

$\bar{\Xi}$ 
However, none of the studies varied the bacterial concentration or cementation regent with the aim of optimizing the basic factors that affect the efficiency of calcite precipitation. Furthermore, the challenges of non -uniformity of calcite formation within the soil can be overcame if the bacterial solution will be mixed with soil prior to sample preparation, thereby changing the method from dry pluviation to wet tampering

\section{Conclusion and suggestion for further studies}

This paper presents a review on bio-mediated soil improvement technique using MICP in the mitigation of liquefiable soil. The field of bio-mediated soil improvement is an emerging area of research which has wide area of application especially in this era of sustainable development. Similarly, in recent times liquefaction has gradually become a cause of serious concern with the expansion of habitation. Generally, the mechanism of liquefaction, commonly adopted method to mitigate liquefaction, MICP, factors that affect MICP and effect of MICP on strength and cyclic response on liquefiable soil were discussed. The following conclusions were drawn from review:

1. The conventional technique used for the mitigation of liquefaction either require high mechanical energy that cause serious disturbance to existing building or chemical admixtures and grouting materials that are known to be harmful to the environment.

2. Urea hydrolysis is the most desired $\mathrm{CaCO}_{3}$ precipitation method adopted by researchers because the process is straightforward and easily controlled

3. MICP have been quite successful in many instances, however, the nonuniform distribution of calcite with in the soil matrix. Some studies showed that calcite is precipitated more at the point of injection rather than the entire soil.

4. A non - destructive method of monitoring the formation of calcite through shear wave velocity should be included in ascertaining the level of cementation and stiffness of treated soil.

5. Cementation level is an important factor that affect the strength properties of MICP treated soil, increase in cementation level leads to formation of larger sized calcite crystals which in turn leads to the improved soil properties.

Even though several researches have been carried out on the use of MICP to mitigate liquefaction, none of the studies have pointed out the effect of various bacterial concentration and concentration of cementation reagent. These are part of the fundamental factors that affect the efficiency of calcite precipitation. Therefore, it is necessary to conduct studies on these factors with a view to optimizing these parameters. Furthermore, most studies on MICP for soil improvement used bacillus pastuerii as urease producing organism, it will be good if other bacteria will be used to compare its efficiency with the commonly used once. Other challenges ahead of the emerging technology is upscaling process, training of researchers/technologist and long - time durability of the improved soils. Regardless of these challenges involved in the execution of this technology, MICP has a wide range of application that can help the present-day concerns through soil improvement.

\section{References}

1. D. Kumari and W.-N. Xiang, "Review on biologically based grout material to prevent soil liquefaction for ground improvement," Int. J. Geotech. Eng., 6362, pp. 1-6, (2017).

2. B. M. Montoya, J. T. DeJong, and R. W. Boulanger, "Dynamic response of liquefiable sand improved by microbial-induced calcite precipitation," Géotechnique, 63, no. 4, p. 302 (2013).

3. R. H. Karol, H. Reuben, and others, "Chemical grouting and soil stabilization," Revis. Expand., 3, pp. 1289$1315,2003$.

4. J. T. Dejong, B. M. Mortensen, B. C. Martinez, and D. C. Nelson, "Bio-mediated soil improvement," Ecol. Eng., 36, no. 2, pp. 197-210, Oct. 2010.

5. J. T. DeJong et al., "Upscaling of bio-mediated soil improvement," Idaho National Laboratory (INL), Oct. 2009.

6. C. Chen, G. Habert, Y. Bouzidi, and A. Jullien, "Environmental impact of cement production: detail of the different processes and cement plant variability evaluation," J. Clean. Prod., 18, no. 5, pp. 478-485, (2010).

7. S. Islam and R. Hashim, "Behaviour of stabilised peat: A field study," 5, no. 17, pp. 2366-2374, 2010.

8. Z. Han, X. Cheng, and Q. Ma, "An experimental study on dynamic response for MICP strengthening liquefiable sands," Earthq. Eng. Eng. Vib., 15, no. 4, pp. 673-679 (2016).

9. H. A. Keykha, A. Asadi, B. B. K. Huat, and S. Kawasaki, "Laboratory Conditions for Maximal Calcium Carbonate Precipitation Induced by Sporosarcina pasteurii and Sporosarcina aquimarina Bacteria," Environ. Geotech., no. January, pp. 1-20 (2018). 
10. J. T. DeJong, M. B. Fritzges, and K. Nüsslein, "Microbially induced cementation to control sand response to undrained shear," J. Geotech. Geoenvironmental Eng.,132, no. 11, pp. 1381-1392 (2006).

11. N. W. Soon, L. M. Lee, T. C. Khun, and H. S. Ling, "Factors affecting improvement in engineering properties of residual soil through microbial-induced calcite precipitation," J. Geotech. Geoenvironmental Eng., 140, no. 5, p. 4014006, (2014).

12. L. Cheng, M. A. Shahin, and R. Cord-Ruwisch, "Surface percolation for soil improvement by biocementation utilizing In Situ enriched Indigenous aerobic and anaerobic ureolytic soil microorganisms," Geomicrobiol. J.,. 34, no. 6, pp. 546-556 (2017).

13. L. Cheng, R. Cord-ruwisch, and M. A. Shahin, "Cementation of sand soil by microbially induced calcite precipitation," 90, no. January 2012, pp. 81-90 (2013).

14. Y. Duraisamy and D. W. Airey, "Performance of biocemented Sydney sand using ex situ mixing technique Performance of biocemented Sydney sand using ex situ mixing technique," J. Deep Found. Inst., 9, no. 1, pp. 48-56 (2016).

15. S. L. Kramer, "Geotechnical Earthquake Engineering Prentice Hall,” New York, (1996).

16. N. Rogers, S. van Ballegooy, K. Williams, and L. Johnson, "Considering post-disaster damage to residential building construction-is our modern building construction resilient," 2015.

17. S. Rupam, "A Review on Soil Improvement Techniques to Mitigate Liquefaction," North East Students Geo-Congress Adv. Geotech. Eng., no. March, pp. 1-6 (2014).

18. R. P. Sharma, "Soil Improvement Techniques for Mitigation of Seismic Hazards - An Overview," in Recent Advances in Geotechnical Earthquake Engineering and soil Dyanamics, 2010, pp. 24-29.

19. Z. et al. Xu, "Experimental Study of the Filling Effect of MICP Microbial Grouting in Silt," 72, pp. 480-484 (2017).

20.. A. Zamani and B. M. Montoya, "Shearing and Hydraulic Behavior of MICP Treated Silty Sand," in Geotechnical Frontiers, pp. 290-299 (2017)

21 M. C. J. Zheng, R. Z. H. Lai, and J. Zhang, "Influence of cementation level on the strength behaviour of biocemented sand," Acta Geotech., 12, no. 5, pp. 971-986, (2017).

22. Wang et al., "Review of Ground Improvement Using Microbial Induced Carbonate Precipitation (MICP)," Mar. Georesources Geotechnol., 35, no. 8, pp. 1135-1146, (2017).

23. C. S. and B. M. Montoya, "Strengthening Coastal Sand Dunes using Microbial Induced Calcite Precipitation," in Geo-Congress 2014 Technical Papers, GSP 234, 2014, pp. 1683-1692 (2014).

24. B. C. Martinez et al., "Experimental Optimization of Microbial-Induced Carbonate Precipitation for Soil Improvement," J. Geotech. Geoenvironmental Eng., 139, no. 4, pp. 587-598, (2013).

25. N. K. Dhami, M. S. Reddy, and A. Mukherjee, "Biomineralization of calcium carbonates and their engineered applications: a review," Front. Microbiol., 4, (2013).

26. S. Al-Thawadi and R. Cord-Ruwisch, "Calcium Carbonate Crystals Formation by Ureolytic Bacteria Isolated from Australian Soil and Sludge,” J. Adv. Sci. Eng. Res., 2, pp. 12-26 (2012).

27. S. Castanier, G. Le Metayer-Levrel, and J.-P. Perthuisot, "Bacterial roles in the precipitation of carbonate minerals," in Microbial sediments, Springer, Berlin, Heidelberg. pp. 32-39. (2000)

28. F. Hammes and W. Verstraete, "Key roles of $\mathrm{pH}$ and calcium metabolism in microbial carbonate precipitation," Rev. Environ. Sci. Biotechnol., 1, no. 1, pp. 3-7 (2002).

29. A. Al Qabany, K. Soga, and C. Santamarina, "Factors affecting efficiency of microbially induced calcite precipitation," J. Geotech. Geoenvironmental Eng., 138, no. 8, pp. 992-1001 (2012).

30. H. A. Keykha, A. Asadi, and M. Zareian, "Environmental Factors Affecting the Compressive Strength of Microbiologically Induced Calcite Precipitation-Treated Soil," Geomicrobiol. J., pp. 1-6 (2017).

31. N. W. Soon, L. M. Lee, T. C. Khun, and H. S. Ling, "Improvements in engineering properties of soils through microbial-induced calcite precipitation," KSCE J. Civ. Eng., 17, no. 4, pp. 718-728, (2013).

32. M. Umar, K. A. Kassim, and K. T. P. Chiet, "Biological process of soil improvement in civil engineering: A review," J. Rock Mech. Geotech. Eng., 8, no. 5, pp. 767-774, (2016).

33.. S. Stocks-Fischer, J. K. Galinat, and S. S. Bang, "Microbiological precipitation of CaCO3," Soil Biol. Biochem.,31, no. 11, pp. 1563-1571 (1999).

34. H. L. Mobley, M. D. Island, and R. P. Hausinger, "Molecular biology of microbial ureases.," Microbiol. Rev., 59, no. 3, pp. 451-480 (1995).

35 K. D. Arunachalam, K. S. S. Sathyanarayanan, B. S. S. Darshan, R. B. Raja, K. D.Arunachalam, and B. Raja, "Studies on the characterisation of Biosealant properties of Bacillus sphaericus," Int. J. Eng. Sci. Technol., 2, no. 3, pp. 270-277 (2010).

36 S. Stocks-Fischer, J. K. Galinat, and S. S. Bang, "Microbiological precipitation of CaCO 3," Soil Biol. Biochem., 31, no. 11, pp. 1563-1571, (1999).

37. Y. Fujita, G. D. Redden, J. C. Ingram, M. M. Cortez, F. G. Ferris, and R. W. Smith, "Strontium incorporation into calcite generated by bacterial ureolysis," Geochim. Cosmochim. Acta, 68, no. 15, pp. 3261-3270 (2004). 
38. V. S. Whiffin, L. A. van Paassen, and M. P. Harkes, "Microbial carbonate precipitation as a soil improvement technique," Geomicrobiol. J., 24, no. 5, pp. 417-423 (2007).

39. V. Rebata-Landa, "No TitleMicrobial activity in sediments: effects on soil behavior.," Phd Thesis, vol. Georgia In, (2007).

40. L. Cheng, M. A. Shahin, M. Addis, T. Hartanto, and C. Elms, "Soil Stabilisation by Microbial-Induced Calcite Precipitation ( MICP ): Investigation into Some Physical and Environmental Aspects,” pp. 10-14, (2014).

41. K. T. P. Chiet. Murtala Umar, Khairul Anuar Kassim, “Temperature Effects On The Strengh Properties Of Residual Soil,". J. Teknol., 3, pp. 101-104, 2016.

42. J. K. Mitchell and J. C. Santamarina, "Biological Considerations in Geotechnical Engineering," J. Geotech. Geoenvironmental Eng., 131, no. 10, pp. 1222-1233, 2005.

43. G. D. O. Okwadha and J. Li, "Optimum conditions for microbial carbonate precipitation," Chemosphere, 81, no. 9, pp. 1143-1148, (2010).

44. M. U. Qureshi, I. Chang, and K. Al-Sadarani, "Strength and durability characteristics of biopolymer-treated desert sand," Geomech. Eng, 12 (5), 785-801 (2017).

45. P. Anbu, C.-H. H. Kang, Y.-J. J. Shin, and J.-S. S. So, "Formations of calcium carbonate minerals by bacteria and its multiple applications," Springerplus, 5, no. 1, p. 250, (2016).

46. J. Xu, Y. Du, Z. Jiang, and A. She, "Effects of calcium source on biochemical properties of microbial CaCo3 precipitation," Front. Microbiol., 6, 1-7 (2015).

47. C.-W. Chou, E. A. Seagren, A. H. Aydilek, and M. Lai, "Biocalcification of Sand through Ureolysis," J. Geotech. Geoenvironmental Eng., 37, 12, pp. 1179-1189 (2011).

48. M. Umar, K. A. Kassim, and Z. Ibrahim, "Microbially induced cementation to improve the strength of residual soil," In Engineering Challenges for Sustainable Future: Proceedings of the 3rd International Conference on Civil, Offshore and Environmental Engineering (ICCOEE 2016, Malaysia, 15-17 Aug 2016) (p. 331). CRC Press, p. 331. (2016)

49. L. M. Lee, "Bio-Mediated Soil Improvement under Various Concentrations of Cementation Reagent," Appl. Mech. Mater., 204, pp. 326-329, (2012).

50. M. Umar, K. A. Kassim, and K. T. P. Chiet, "Biological process of soil improvement in civil engineering: A review" J. of Rock Mechanics and Geo. Eng," 8, 767 - 774(2016).

51. K. T. P. Chiet, K. A. Kassim, K. B. Chen, U. Martula, C. S. Yah, and A. Arefnia, "Effect of Reagents Concentration on Biocementation of Tropical Residual Soil," in IOP Conference Series: Materials Science and Engineering, 136, (2016).

52. A. Al Qabany et al., "Factors affecting efficiency of microbially induced calcite precipitation," J. Geotech. Geoenvironmental Eng., 138, no. 8, pp. 992-1001 (2012).

53. T. M. E. Peng Xiaoa, b, Hanlong Liua, b, Yang Xiaoa, b, *, Armin W. Stuedleinc, "Liquefaction resistance of bio-cemented calcareous sand," Soil Dyn. Earthq. Eng., 107, pp. 9-19 (2018)

54. M. Simatupang and M. Okamura, "Liquefaction resistance of sand remediated with carbonate precipitation at different degrees of saturation during curing," Soils Found., 57, no. 4, pp. 619-631, (2017).

55. T. Sasaki and R. Kuwano, "Undrained cyclic triaxial testing on sand with non-plastic fi nes content cemented with microbially induced CaCO 3," Soils Found., 56, no. 3, pp. 485-495, (2016).

56. H. Zhiguang, C. Xiaohui, and M. Qiang, "An experimental study on dynamic response for MICP strengthening lique fi able sands Abstract :," 15, no. 4, pp. 673-679 (2016).

57. M. B. Burbank et al., "Urease Activity of Ureolytic Bacteria Isolated from Six Soils in which Calcite was Precipitated by Indigenous Bacteria Urease Activity of Ureolytic Bacteria Isolated from Six Soils in which Calcite was Precipitated by Indigenous Bacteria,” 451, no. October 2016, 2012.

58. K. Feng and B. M. Montoya, "Quantifying Level of Microbial-Induced Cementation for Cyclically Loaded Sand," J. Geotech. Geoenvironmental Eng., 143, no. 6, p. 6017005 (2017).

59. B. M. Montoya, "Bio-mediated soil improvement and the effect of cementation on the behavior, improvement, and performance of sand," J. Appl. Microbiol., Oct. 2012.

60. K. Feng and B. M. Montoya, "Quantifying Level of Microbial-Induced Cementation for Cyclically Loaded Sand," J. Geotech. Geoenviron. Eng.,143, no. 6, pp. 1-4, (2017).

61. K. Feng and B. M. Montoya, "Drained Shear Strength of MICP Sand at Varying Cementation Levels," Ifcee, pp. 2242-2251 (2015). 